\title{
Cultural Pattern of Rhetorical Move in Indonesian Students’ Speeches
}

\author{
Oikurema Purwati \\ The State University of Surabaya, Surabaya, Indonesia
}

\begin{abstract}
In analysing a speech genre, genre analysis is applied. Genre analysis is a recent trend in discourse analysis. It combines socio-cultural and psycholinguistic aspect of text construction and interpretation. This analysis aims to show what extent surface linguistic forms align with given standardized communicative events. To construct a text, a speaker should master its schematic structure. The schematic structure consists of organizing the rhetoric. It covers the macro-stages which can be classified into introductory stage, body stage, and concluding stage. The rhetorical organization/structure (micro moves) of a speech genre includes "opening marker”, "gambit”, “narration”, and “marker” in the introductory stage; “claim”, “confutation”, “confirmation”, and “concession” in the body stage; “marker”, “appeal/recommendation”, and a closing in the body stage. By studying the schematic structure, it can be recognized how the students construct the genre, whether they follow the linear pattern offered or their construction of speech is influenced by their native cultural way of thinking. In sequencing the micro moves, the students followed the sequence offered in the framework of speech genre. Although there was a slight difference in sequencing the moves, in general the students have conformed to the proposed sequence. The variety of sequencing the moves was prompted by the native language and cultural background (Javanese and Chinese). Since rhetorical organization varies from culture to culture, it can be tolerated that the students have a variety in sequencing the moves.
\end{abstract}

Keywords: genre analysis, move, hortatory exposition, culture, speech

\section{Background}

As a global means of communication, English as an international language can be taken into consideration. Entering the twenty-first century, acquiring English is essential to participate in global changes. Therefore, English, as a significant means of communication in the world, should be proficiently mastered. Using English as a foreign language effectively involves more than mastering its vocabulary and structure. It involves thinking differently about language and communication. To communicate in another language, especially English, the speaker should have knowledge of a broader discourse competence that involves the ability to interpret and critically evaluate a wide variety of texts (Kern, 2000). Consequently, to be able to use English the English way, the English learners are required to master certain components to create a text (discourse).

Oikurema Purwati, EngGradip, M.Appl., Ph.D, Department of English, The State University of Surabaya. 
According to Black (1995), a text is any meaningful stretch of language-oral or written. However, not all texts are the same. They have different ways of expressing based on different functions and purposes (p. 17). Derewianka (1995) mentions that language choices are available within any particular situation, and in which choices are more likely to result in an effective text which achieves its purpose (p. 17). Spoken and written modes have different language choices and purposes. Each purpose is structured differently based on schematic structure (rhetorical organisation). When the schematic structure of a text helps it to achieve its purpose, it can be considered as genre. Familiarity with genres is important in communication, because it allows a connection to be made between particular instances of discourse and others. Once, a particular genre is identified, what is coming can be anticipated, as well as a sense of what details may be significant (Kern, 2000, p. 87).

Considering a genre, spoken genre (discourse) should be the important goal of foreign language education, given the opportunities created by the global marketplace (Kern, 2000, p. 5). Effective oral communication generally requires "literate" sensibilities about the particular ways the foreign language can be used in particular settings, not to mention a familiarity with the cultural premises that underlie all communicative interactions within the targer language. Hence, the use of language should be meaningful and purposeful. Related to different purposes and functions oc communication, Black (1995) states that different situations and cultures carry different ways of speaking (p. 143). For example, taking a taxi in Addis Ababa is different from taking one in Sydney. Furthermore, he continues, buying something from a shop or a market in such countries as Ethiopia can involve a stage of bargaining not found in western service encounters. As a result, the teaching of oral communication skills as a contextualized sociocultural activity has become the focal point in many EFL classrooms (Savignon, 2001, p. 103). Consequently, EFL learners need explicit instructions in the speaking class because oral communication in a foreign language requires the ability to use the language appropriately in social interaction (Shumin, 1997, p. 9).

Considering two basic aims of all education, self-realisation and social adjustment, speech making is necessary to be acquired. Balce \& Seabury (1965) say that speechmaking helps to develop thinking, articulate participation, and consciousness of responsibility, and social adjustment (p. 22). Furthermore, they suggest that public speaking includes ideas selected for communications under the conditions of the speech situations, arrangement of ideas for the purpose of getting from the listener the response desired by the speaker, and phrseology of the selected thoughts in language approppiate for the listener in the sppech situation. In other words, effective speech serves maximum efficiency in self-expression and in communication, is purposeful, is easily understood, and is provocative of thought, ideas, affective states, or action. In line with this, the 2006 English Curriculum requires graduates of the senior high school to be able to express their thinking orally, to take part in society in which English is used, to be able to think analitically and imaginatively (BSNP, 2006, p. 307). For this purpose, participating in a speech contest can be considered as a good exercise for the SMA (high school) students to practice how to use the language appropriately and to present their thoughts logically and critically. At the same time, the students may imaginatively offer a solution by appealing to do an action.

Delivering a speech in a speech contest can be regarded as an opportunity for the students to demonstrate their ability in the spoken language. The ability to be able to use English orally is explicitly stated in the curriculum. The oral competences required by the senior high school students in Indonesia are presented by the indicators. Some indicators (actional competence required to present a speech) are asking and giving opinions, 
showing agreement and disagreement, able to identify and write the rhetoric of hortatory exposition in the second semester of grade XI (BNSP, 2006, pp. 318-320). The requirement to compose hortatory exposition means that the students are required to be able to explain and influence the audience about something. The structure of the text is organised from the statement of the issue, followed by arguments and ended with a recommendation (Depdiknas, 2004, p. 42). Thus, the students are expected to be able to argue logically and critically and offer a way out. In delivering a speech, the students argue about a certain topic. While they are presenting their ideas, at the same time they appeal to the audience to do something. In other words, it is recommended that the students must acquire the ability to argue and to appeal while presenting a speech.

Lazaraton (2001) suggests presenting speeches as another common activity in the oral skill class (p. 106). The organization of a speech is similar to the schematic structure of one of the acquired texts, hortatory exposition, which must be achieved in the second semester of grade XI. As a consequence, the structure of a speech-its rhetorical genre should be taught to the students. The content, organisation and language features (grammar, vocabulary, fluency, pronunciation) of a speech must be explained clearly. This activity not only gives students more actual practice with speaking the language but it also forces them to think and speak in English. In addition, students are also equippped with the ability to argue so that they will have the skill to argue orally. It is also known that speaking has many grammatical features that gunction quite differently from those found in written language (pervasive, an initial slot to introduce topic, tails for amplification or extension, and reporting verbs). Thus, teaching how to present speeches enables students to make the choice in spoken discourse and develop some sensitivity to differences between the spoken and the written language (Celce-Murcia \& Olshtain, 2000, p. 170). Often, in preparation for such a formal speaking task as presenting a speech, a written draft or outline is produced. However, in presenting an oral speech, a speaker should not only master written linguistic features for the speech preparation but also spoken linguistic features such as suprasegmental features (tone, intonation, pitch, and pronunciation) when delivering the speech.

In practice, giving a spech in front of an audience is taught only as a concomitant, meaning that speech is not the main objective of teaching. The students are assigned to deliver a speech on special occasions, in social events at school, such as cultural nights, graduation ceremonies, or in a speech contest. Instead of explaining explicitly the structure of a speech, in reality the students are given assignment to submit a written draft of a speech. To fulfill their teacher's assignment in making a speech, the students try to make it on their own with insufficient knowledge of constructing a speech. However, the teacher does not return the students' work with adequate feedback to improve their speech. This condition is due to the fact that language teaching still focuses on the national tests, where language is treated as a knowledge subject—analysed, explained, and practiced in much the same way as other subjects. Based on some teachers' comments, they have to cover all the material for the national tests. Therefore, most English teachers do not have time to focus on oral skills, such as speeches (Yang, 1999, p. 22).

Although in reality the focus of teaching of English on the national tests, the students still have the opportunity to practice their ability in English by joining a speech contest. Applying their own knowledge in English which they may get from school and other activities concerning English such as taking English course, reading English books, watching movies or listening to English songs, the students can show their competence in speech making. In general, they already know that a speech consists of three general stages (introduction, body, 
and conclusion). In addition, they have to be able to construct good and appropriate sentences in English. They have to be able to choose the correct words. At the same time, they are also acquired to organize a speech the English way. In this opportunity, the students as the participants of speech contests are required to have discourse competence in which the students have to be able to produce appropriate sentences, expressions and the rhetorical organization.

It is believed that a student who participates in a speech contest is considered having the ability in using English. In fact, the students get her/his knowledge of composing a speech not only from formal teaching-learning process in the class but also from other sources. It cannot be denied that the student gets the knowledge of constructing the speech not only from her/his Englisg teacher's explanation but also from her/his own effort. She/he may read books concerning speech making, including the examples of well-known speeches, or ask other people who know English.

The students who follow a speech contest should master the strategy to speak in front of an audience. They should know how to present ideas and negotiate meaning in a shared context (Shumin, 1997, p. 10). Being in front of others and being expected to speak can be an intense, menacing source of tension and can strongly determine a student's level of participation (Yang, 1999, p. 22). Without having adequate knowledge in speech making skills, ubiquitous features of spoken language (slang and idioms), the speech participants are apt to sound bookish (Savignon, 2001, p. 17). While presenting the speech, the speakers can be regarded as speaking like a book. They do not know how to use the language socially and culturally appropriate. Accordingly, speech must be taught in the classroom as the main goal of teaching as the requirement of the recent curriculum to provide knowledge, not only linguistic but also aesthetic, to deliver a speech. By participating in a speech contest the students truly show their mastery of English and text organization. Although before presenting the speech, the committee of the speech contest asked for the written version of the speech, these outstanding students deliver their speeches without looking at their written text. Instead, they are able to deliver a speech like good orators. Those who memorized the speech would forget their speech and they could not continue their speeches.

A speech as a genre, conventionally consistes of an "introduction", a "body", and a "conclusion". Besides the three macro stages, speech is a special type of discourse which also consists of micro moves (rhetorical organization). The moves of the speech can be considered as sequencing the thought pattern. In addition, the organization of a speech may follow a certain generic structure, such as issue, argument, recommendation, position argument and summing up. Therefore, in delivering a persuasive speech the purpose and the generic structure which can be considered as the rhetoric should be set up clearly.

Once language learners who learn English as a foreign language, have been equipped with all the neccessary elements to compose a persuasive speech genre, it is expected that they can deliver a well-organized speech. However, their first language may interfere with their way of thinking. Based on the theory of language relativity (Sapir \& Whorf), the language perceived may influence the way of thinking. Based on Sapir-Whorf hypothesis, our view of the world is dependent on the structure of our language (Black, 1995). Birk and Birk say that language shapes our perception of reality. How we use words - the exact language we select and the emphasis we give it—has the power of shaping somebody’s else judgement on a subject (Birk \& Birk, 1986). 


\section{Review of Related Literature}

\section{The Relationship Between Language, Culture, and the Way of Thinking}

The nature of the relationship bewteen way of thinking (thought), culture and language is a question that has long aroused the interest of not only lingusts, but also anthropologists, psychologists and philosophers since the of Boas, Sapir and Whorf (Ngadiman, 1998, p. 31). The connection between thought, culture and language is expressed, among others, in the lexical aspect as found by Bloomfield (Blount, 1974, pp. 86-111; Ngadiman, 1998, p. 32). The Arabic language, for example, includes 6,000 terms that refer to specific types and variations of camels or that are derived from the basic word for camel, and camels in various stages of pregnancy (Ngadiman, 1998, p. 32). Similarly, among the Eskimos, there are many different terms for snow (Blount, 1974; as cited in Ngadiman, 1998, p. 32). The constant presence of snow and the importance it has in the lives of Eskimos is reflected in their language. Eskimos have different words for 'snow in the ground', "falling snow", "drifting snow", and "snow drift". In Javanese which is an agricultural society where the people live on rice, the presence of rice is also very significant (Ngadiman, 1998, p. 32). The importance it has in their lives is reflected in the language. javanese, therefore has many terms that refer to the specific types of rice: ketan, ketan ireng, ketan abang, gaga, mrening, jawa, boing, pulen, and many others. There also many terms referring to variations of the product of rice: pari, gabah, sego, intip, menir, dedek, karak, meniran, lontong, jadah, pondoh, bubur, kupat, tumpeng, golong, and so on (Ngadiman, 1998, p. 32).

Based on those cultural variations, Kaplan finds five types of rhetoric. The first type is the Anglo Saxon model. The expected sequence of thought in this type of rhetoric is essentially shaped subsequently by Roman, Medieval European, and later Western thinkers (Ngadiman, 1998, p. 34). The typical characteristic of this rhetoric is that it is dominantly linear. This linearity of thought pattern is manifested in the development of thought within a paragraph which is the smallest unit of a discourse. The second type of rhetoric is the semitic model which is developed in Arabic-Persian languaes. In the Arabic language, for example, paragraph development is based on a complex series of parallel constructions. There are synonymous, synthetic, antithetic and climatic parallelisms. Synonymous parallelism refers to the balancing of the thought and phrasing of the first part of a statement or idea by the second part. The two parts are often connected by a coordinating conjunction. The third type of rhetoric is the model which is commonly found in Asian languages, such as Korean, Japanese, Hindi, Indonesian, etc. This model is marked by what may be called an approach by indirection. In this kind of rhetoric, the development of the paragraph may be said to be "turning and turning in a widening gyre". The circles turn around the subject and show it from a variety of tangential views, but the subject is never looked at directly. Things are developed in terms of what they are not, rather than in terms of what they are (Ngadiman, 1998, p. 37). The fourth type of rhetoric is the Franco-Italian model. This model is commonly found in french, Spanish, and Italian. This type of rhetoric is marked by digression. The fifth type of rhetoric is the Slavic model including Russian. This model of rhetoric has a clear beginning and end, but in the middle there is much material that is irrelevant to the development of the argument.

Without understanding a culture of certain language, it would be difficult to communicate. When someone goes to live in another country and is told to come and visit the native people at home, should one quickly accept the invitation, or should one assume, as people might do in Japan, that they do not really expect a foreigner to take 
them up on? If someone goes to a party and is urged by the host to eat something, should she/he refuse a couple times, as an Arab might do, or quickly accept to avoid being left to hungry? If someone is talking to another about her baby, would saying "What big brown eyes she has!” be taken as a compliment or, as in some Aboriginal cultures, an insult? (Black, 1995).

\section{The Notion of Genre}

Texts (genres) are distinguished according to their goal orientation and examined to determine how they are structured to achieve specific ends. This involves revealing how texts are typically sequenced in the context of a particular text type. When the purposeful use of language proceeds in a number of stages we can speak of it in terms of a genre of language, whose associated pattern can be called its generic structure (Black, 1995). The term genre as defined by Martin, namely 'a staged, goal oriented, purposeful activity in which speakers engage as members of (their) culture', similar to taking a taxi in certain place or buying something from a shop or a market in such countries (Black, 1995, p. 143).

The term "genre" has been used in literary study, such as drama, poetry, and prose. In linguistics, it refers to different text-types. Hammond clarifies that genre theory is a theory of language use (Hammond, 1987, p. 165). Another definition of genre according to Swales is a class of communicative events, the members of which share the same set of communicative purposes (Cheong, 1999, p. 45). According to Derewianka (1995, p. 18), the genre of a text is partly determined by the culture in which the text is used, since different cultures achieve their purposes through language in different ways. In conclusion, when communicating people create texts/genre (Agustien, 2004, p. 2).

Martin treats genre in a wider sense, referring to it as a contextual (cultural) variable, which is interpreted as a connotative semiotic (Martin, 1984, p. 25; Sinar, 2002, p. 56). Genre is a term that is defined to capture the notion of context of culture, which stands as one of the semiotic systems outside language (i.e. two levels above it), which is not intrinsically part of his register plane but one level above it. In this respect the relation between genre, register and language is one realisation: genre is realised by register and language, register is realised by language.

Genre relates to the cultural purpose of the text and reflects the stages a text goes through in achieving its social purpose (Black, 1995). Genres are most simply different text types used to do different jobs in a culture. Genres have characteristics schematic structure and lexico-grammtical patternings which change as one part of the text's purpose is achieved, thus allowing the text to be seen as a number of stages. That is, texts doing more or less the same job in a culture will most likely have similar patterns. A genre is recognised by its global or overall structure and by its lexico-grammatical patterns. For instance, buying and selling could be seen as a social purpose which has the potential to be realised through a number of genres, such as auctions, going to a supermarket, going to a corner shop, and bargaining at a market. All of these are ways of achieveing the same social purpose, ie conveying something in exchange for something else, but the genre chosen to achieve this end depends on both cultural and immediate social contexts.

Halliday uses the term "lexicogrammar" in preference to "grammar" or "syntax". Lexicogrammar is used because this level or stratum of language is seen as including grammar, lexis (words) and morphology. A language is interpreted as a system of forms, to which meanings are then attached (Wignell, 1994, p. 32). In a 
functional grammar, a language is interpreted as a system of meanings, accompanied by forms through which the meanings can be realised.

\section{Genre Analysis}

Genre analysis, in linguistics, has concerned itself most with describing the higher level organization and structure of written or spoken texts. Swales (1985) and Bhatia (1993) proposed genre analysis, a model of patterned discourse which is one of the new trends in discourse analysis. Genre analysis combines socio-cultural and psycholinguistic aspects of text construction and interpretation with linguistic insights, in order to answer the question, "Why are specific discourse genres written and used by the specialist communities the way they are?”. The current interest in genre analysis obviously stems from the constantly increasing role of English as the international language of scientific, business, and cultural communication. Consequently, there is need for a better understanding of the structure and function of a specific genre in this process.

Swales defines a genre as "a class of communicative events, the members of which share the same set of communicative purpose". Examples of similar genre share similarities in "structure, style, content, intended audience, and rhetorical movement”. The study of genres aims to show to what extent surface linguistic forms align with given standardized communicative events. Swales designed moves and they contain a number of component steps signaled by specific linguistic signals. Genres are also characterized by similarity in their "rhetoric movement".

Since the mid 1980s, genre analysis has become a rich area of research (Cheong, 1999, p. 44). Among the genres which caught the early and active attention of applied linguistic, particularly in the field of ethnolinguistics and sociolinguistics are those that pertain to academic and the professions, specially the research report or scientific journal article, and business letters. The current interest in genre analysis obviously stem from the constantly increasing role of English as the international language of scientific, business and cultural communication. Moreover, it is known that particular genre shares similarities in "structure, style, content, intended audience and rhetorical movement" (Swales, 1990, pp. 58-140). Swales designs moves and they contain a number of component steps signaled by specific linguistic signals.

Taking communicative purpose as the key characteristic feature of a genre, genre analysis has become one of the major influences on the current practices in the teaching and learning of languages (Bhatia, 1997, pp. 134-135). Genre analysis is the study of situated linguistic behavior in institutionalized academic or professional settings. It has the four following characteristics, as follows:

- Rather than providing a detailed extension, validation or otherwise of one linguistic framework or the other, genre analysis shows a genuine interest in the use of langauge to achieve communicative goals. In this sense, it is not an extension of linguistic formalism.

- Genre analysis does not represent a static description of language use but give s a dynamic explanation of the way expert users of language manipulate generic convention to achieve a variety of complex goals. In this sense, it combines the advantages of a sociolinguistics perspective, especially the use of ethnographic information, with those of a cognitive perspective, especially regarding the tactical use of language.

- It is primarily motivated by applied linguistic concerns, especially language teaching at various level. 
- It is narrow in focus but wide in vision, focussing on specific differentiation in language use at various levels of generality.

\section{The Nature of Rhetoric}

Rhetoric is a term which is commonly used by politician, government body, or people in the House of Representative. Rhetoric is usually used in giving speeches to inform the government's national planning or the government's report. Rhetoric is defined as the art or the science communication in words (Webster, 1990). Genuine rhetoric occurs when a communicator presents an informative or suasory ethical verbal (written or oral) or non-verbal message specifically designed to create a persuasive effect in an audience comprised of readers or listeners who have a choice or perceived choice and the power to modify the exigencies upon which discourse is constructed (Golden et al, 1984).

Rhetoric according to Kaplan (1980, p. 399) is the use of symbols to influence thought and action. Rhetoric is a mode of thinking or finding all available means for the achievement of a desired end. In other words, rhetoric basically deals with what goes in mind rather than what comes out of the mouth. Kapaln finds five types of rhetoric (1966) in Ngadiman (1998, pp. 34-38). Rhetoric, then is concerned with factors of analysis, data gathering, interpretation and synthesis (Wahab, 1981, p. 195). Moreover, studies of rhetoric, which belong to the interest of discourse analysis (i.e. text analysis) principally investigate the thought patterns of the writers. As is stated by Nutal (1982), in the text the writers' thought is displayed into a pattern into which rhetorical acts are sequenced and organized (Susilo, 1998). Therefore, in delivering a speech, the learner's way of thinking is also influential. As mode of thinking takes part in learner's mind, the composition of persuasive speech should follow the organization of the schematic structure of a persuasive genre. By following the schematic strcture and its moves, the speakers are able to present their ideas logically and critically.

\section{Rhetorical Move of Persuasive Speech Genre}

In general, persuasive speech genre follows the schematic/generic structure of persuasive text in which argumentative and persuasive maxims are applied. However, this genre can be analysed after being transcribed. The components of persuasive speech genre are schematic/generic structure, rhetorical moves and functions, and language features.

The ability to deliver a persuasive speech genre in English, in front of audience can be achieved if an English learner has learned and mastered the components of this genre. The English learner may get the model how to deliver a speech from television show, such as a president's inaugural speech or a leader's speech. An English teacher may add the exposure to practice delivering this speech genre during the process of teaching and learning.

In public speaking, schematic/generic structure of a persuasive speech genre consists of three major stages, namely introduction (consisting thesis), body (consisting argumentation), and conclusion (consisting reiteration or recommendation). In each of the stage, there are different rhetorical moves. In the stage of introduction, the rhetorical moves are opening marker, gambit (attention grabber), narration (background information), marker (introducing proposition/isue). In the body, the rhetorical moves include claim, confutation, confirmation, and concession. In the last stage, conclusion, the rhetorical moves are marker, appeal/recommendation, and closing. 


\section{Methodology}

\section{Text Analysis}

Text is defined as a 'communicative event' that must satisfy several conditions, namely seven criteria (de Beaugrande \& Dressler, 1981, p. 1; Tischer et al., 2000, 21). According to this definition, a traffic sign, a newspaper article, an argument and a novel are all texts that correspond to the differing rules of particular genres or text types which have particular linguistic features, fulfil particular functions and are bound to specific production and reception situations (Swales, 1991; Tischer et al., 2000, p. 21). The first criterion is cohesion which concerns the components of the textual surface, that is the "text-syntactic" connectedness. The second criteria is coherence (textual semantics) which constitutes the meaning of a text. The following criterion is intentionality which relates to the attitude and purpose of text producers. The fourth criterion is acceptability as the mirror of intentionality, it means that a text must be recognized as such by recipients in a particular situation. Then, informativity refers to the quantity of new or expected information in a text. Situationality means that the talk-constellation and speech situation play an important role in text production. The last criterion is intertextuality which means that a text has two types of meaning. One, it suggests that a text always relates to preceding or simultaneously occuring discourse, and on the other hand, it also implies that there are formal criteria that link texts to each other in particular genres or text varieties.

Discourse theory provides paths or mapping both from situation to language, explaining how or why particular uses of language were chosen, and from language and situation to effect, explaining why particular uses of language succeed or fail to form a text. Texts have a kind of wholeness or integrity. According to Mann \& Thompson (1992, p. 41), the organization of a text is called "structure". Therefore, a theory that discusses how a text is structured is named Rhetorical Structure Theory. This theory of text structure describes what sorts of part of texts have and the principles of combinations of parts into entire texts. How a text is structured is shown in the following basic assumptions, namely organization, unity and coherence, unity and coherence arise from imputed function, hierarchy, homogenity of hierarchy, relational composition, asymmetry of relations, natue of relations, and the number of relations.

\section{The Implementation of Moves in the Introductory Stage of the Students' Speeches}

In regard to cultural interference, some speakers employed their native cultural background. In delivering the sppeches, 5 out 8 speakers started to greet as the "opening marker” with "Assalamu'alaikm Warohmatullahi Wabarokatuh" (peace be upon you in the mercy of God and His blessings). It can be seen in the society, this kind of greeting is widely used, even in formal situations such as cabinet meeting, parliamentary meeting, seminar and other formal activities. It is common in the society to use this kind of salutation, even the speaker is a non-Moslem. So that, it is not surprising that the speakers used this kind of greeting. In addition to this greeting, showing gratitude to God is also common way to express in the beginning of the speech. After addressing the audience, the salutation includes expression of showing gratitude to the God. In a certain style, the speech participants began the salutation with Islamic greeting and followed by showing gratitude to the honorable guests and participants as it is commonly used in presenting a speech. After greeting as the component of "opening marker" the speakers continued with "gambit" which functions to capture the attention of the audiences, rather than to inform. To grab the attention, there is a tendency to state a "surprising/interesting” statement, such as: 
- I begin my speech with a story.

- I will give you no evidence.

- ... they may have a sin in the society.

- Right, let me take example from my class.

- Oh, I’m sorry.

- ... human beings are created to face problems and death.

- ... Bali is still safe for tourists.

- Right. And how to increase human recourse?

Initiating a speech with a story could attract the audience's attention. The audience might be interested to know what kind of story would be told. Then, giving no evidence in a speech is something "odd/strange" as it is known that in delivering a speech, facts or arguments should be stated. The word 'sin' could grab the emotion of the audience. The audience would be curious what kind of sin could be done by young generation as the topic of the speech. While a phrase such as "I'am sorry" in the beginning of a speech could be confusing. However, apologetic opening is used in Javanese text (Ngadiman, 1998, p. 165). It may be presented after the salutation or addressing the audience. The word "death" may stimulate a scary feeling. Here, it may arouse the attention of the audience.

Before stating the issue, "narration” (as one of the moves in the introductory stage), functions as background information to give audience an information of the topic/issue being discussed. However, one of the speakers, coming from Chinese family background, presented a real narration. She told two stories before stating the issue. It can be understood that 'delayed thesis statement' occurs in some cultures, such as Japanese, Korean, and Chinese (Ngadiman, 1998, p. 49). Sometimes the issue discussed involves words which may produce misunderstanding. Therefore, the 'narration' move should be applied to give information before stating the issue.

The most important move in the introductory stage is stating the issue. The issue is any topic of concern and controversy (Cooper \& Patton, 2003, p. 87). The issue stated can be considered as the thesis of the speech. This is called "marker" move, as follows:

- Today, I'm going to talk about 1095 amazing and magical days that we've been through or we are going through, high school years.

- Just to issue—-say about why high school year is the best years in our life.

- The young generation is an important assets for our country.

- Ehm, I guess I can tell you a little about my experience of being high school students and how it makes me real happy to be.

- In this occasion, please allow me to talk about the young generation is an important assets for our country.

- Today, I'm going to deliver a speech about something, not so far from us but close to us, and we do this everyday. I mean face it everyday.

- In this occasion, please allow me to speak in front of you about Bali is still safe for tourism.

- So now young generation is so important for building this country.

Based on the statements above, it can be seen that most of the contestants used "verbal process" to state the issue of their speeches. The verbs include to talk, to say, to tell, to deliver, and to speak. The phrases such as "magical days", "the best years", and "makes me real happy” show that the speakers support the topic that "high 
school time" is the best time. The word "magical", "best", and "happy" mean something positive. Here, the speakers enjoyed their high school time. To discuss "the young generation”, three speakers agrred that the young generation is an important asset. While in discussing "Bali bombing", the speaker felt disappointed with the bombing and hoped that many tourists would visit Bali again. To talk about SARS, the speaker suggested to face it by doing prevention.

\section{The Implementation of Moves in the Body Stage of the Students' Speeches}

In logic, an argument is not a fight but a rational piece of discourse, written or spoken , that attempts to persuade the reader or listener to believe something. The moves in the body stage are classified into "claim", “confutation”, “confirmation”, and "concession”. The sequence of moves can be repeated in the body stage.

The central move in the body stage is 'claim' which states reasons for acceptance of the proposition. "Claim" is a statement upon which an argument is based or from which a conclusion is drawn (D'Angelo, 1980, p. 241). "The problems faced by the students can be the great teachers in high school" is the argument which was elaborated into consequences, such as achieving maturity. Instead of giving reasons, the argument about high school time is the best time by giving the examples of happenings, such as happiness and sadness as the components of process of life. To argue that young generation is an important asset, the speakers explained facts (the real problem faced by the students) such as drugs, following western culture, doing school assignments (homework, projects or tests). In 'Bali bombing' the speaker refers to the authority (government) to capture the bombers. Arguing about SARS, the speaker gave fact about the number of victims, the name of the virus, and its prevention.

The formal pattern of disagreement with another's argument is called "confutation" (refutation). Confutation presents a counterargument and the explanation why thus position is false, misleading, irrelevant, or weak; discredit it in some well-reasoned way. This move does not simply point an accusing finger at another's argument. It demonstrates in an orderly and logical way (Seyler, 1984, p. 147). Based on the statements above, it can be considered that they are able to give argument opposing the "claim" (proposition). While in the "claim" of "high school is the best time" as the issue, they confuted that high school time was "the worst time" by having problems and feeling sadness. Issuing 'the young generation is an important asset', they gave counterargument by mentioning the condition of young generation today as drug takers, Western culture followers, or being left behind in technology. In talking about SARS, the speaker voiced concerns about the effects of disease to the society. While, discussing Bali bomb, the speaker questioned about the government's act to catch the bombers. It means that the winners of the speech contest were able to offer a logical and critical counter argument. At the same time, they were able to perform unemotional persuasive speeches.

Confirmation presents evidence that supports the issue. Confirmation is something that confirms, a proof to make something stronger or more persistent and finite (Cayne, 1989, p. 2040). Applying the "confirmation" move, it seems that the speakers were able to suuport the ideas stated in the "claim". To confirm their arguments, the speakers who discussed "high school time is the best", stated that all kinds of things which happened in high school taught them to mature. They matured by understanding themselves (their personalities) and their need. In discussing that "young generation is the best asset", the speakers were able to confirm the audience that as an asset, the young generation should equip themselves with education, ability to express their aspiration, and the 
need of mastering technology. Talking about SARS, the speaker could confirm that unhealthy environment could trigger disease. In confirming that 'Bali bomb' is not beneficial, the speaker showed facts that people were scared to visit Bali.

Concession demonstrates that counterargument is taken into consideration. It shows that the opposing side's point of view is considered. Concession means conceding, that which is connected, especially after discussing a different opinion or an argument. In the speeches analysed, the speakers could come to the conclusion after arguing in the "claim", "confutation”, and "confirmation". In discussing "the high school time is the best time", they stated the problems and difficulties during this time. To concede that "young generation is an asset", the speakers could support that young generation is important asset instead of their lack of education, information, and technology. In the other topic, the speaker conceded that virus of SARS came from animals. Instead of considering Bali as a "destroyed" place after the bombing, the speaker conceded that Bali is still a beautiful island.

\section{The Implementation of Moves in the Concluding Stage of the Students' Speeches}

The concluding stage of a persuasive speech text functions to recall the ideas presented in the body stage and to make an appeal or recommendation. The moves in the concluding stage are "marker", "appeal/recommendation", and "closing". The significant characteristic of a persuasive speech is the "appeal/recommendation” because this stage offers "a way out” to a certain problem in the argumentative section. "marker" is a move to give conclusion. The "marker" here can be considered as the restatement of the "marker" in the introductory stage. In this occasion, the speaker may remind the audience about the issue presented in the body stage. When three speakers stated that "high school time is the best time", they restated it as their conclusion. While the other three speakers considered that "young generation is important", they issued it again as the conclusion. Once, a speaker assured that "Bali is safe", she mentioned in the conclusion that "Bali is still a special place”. To give conclusion about 'SARS', the speaker offered to keep environment clean and healthy.

It seems that all speakers know that in presenting a speech, the "marker" in the introductory stage should be similar to the "marker" in the concluding stage. According to Fawcett and Sandberg (1988), a conclusion signals the end of a text and gives a final thought (p. 274). They continue that the "thesis" proposed in the introduction ("marker") may be restated in the conclusion (marker). In the beginning of concluding stage, the "thesis" in the introductory stage is repeatedly mentioned as a conclusion. The "marker" in concluding stage is like a restatement of the "marker" in the introductory stage. The speakers were able to keep the unity or wholeness of the ideas presented in their speeches by restating the "marker" of the introductory stage in the "marker" of the concluding stage. The speakers could keep the flow of their ideas by keeping the idea in the "marker" of the introductory stage and the "marker" in the concluding stage. It means that the speakers in the speech contests were able to present linear ideas. The Table 1 shows the similarity between "marker" in the introductory stage and "marker" in the concluding stage. 
Table 1

The Comparison of "Marker" in the Introductory Stage and in the Concluding Stage

\begin{tabular}{|c|c|c|}
\hline Speeches & $\begin{array}{c}\text { "Marker" } \\
\text { (Introductory stage) }\end{array}$ & $\begin{array}{c}\text { "Marker" } \\
\text { (Concluding stage) }\end{array}$ \\
\hline 1. & $\begin{array}{l}\text { Today, I'm going to talk about } 1095 \text { amazing and } \\
\text { magical days that we've been through or we are going } \\
\text { through high school years. }\end{array}$ & $\begin{array}{l}\text {... remember just love your high school to open your } \\
\text { mind toward the big real world that in front of you, } \\
\text { make that time as the best time in our life, explore } \\
\text { our talent, improve ourselves, but find out what we } \\
\text { can do to improve ourselves and i believe that will } \\
\text { the best time in our life. }\end{array}$ \\
\hline 2. & $\begin{array}{l}\text { Just to issue ... say about why high school year is the } \\
\text { best years in our life. }\end{array}$ & $\begin{array}{l}\ldots . \text { it's also just to find the joy in the process when } \\
\text { you are in the high school years ... You see this our } \\
\text { life, this the time when we feel very happy and also } \\
\text { in the other end we will feel very sad. The time when } \\
\text { we drowned in black color but also comes back with } \\
\text { colorful smiles. }\end{array}$ \\
\hline 3. & $\begin{array}{l}\text { The young generation is an important assets for our } \\
\text { country. }\end{array}$ & The young generation is important for our country. \\
\hline 4. & $\begin{array}{l}\text { Ehm, I guess I can tell you a little about my } \\
\text { experience of being high school student and how it } \\
\text { makes me real happy to be }\end{array}$ & $\begin{array}{l}\ldots \text { talking about how high school can be the best time } \\
\text { for a person's life and can take forever }\end{array}$ \\
\hline 5. & $\begin{array}{l}\text { In this occasion, please allow me to talk about the } \\
\text { young generation is an important assets for our } \\
\text { country }\end{array}$ & $\begin{array}{l}\ldots \text { the young, the potential and qualified young } \\
\text { generation can improve our country. Can make our } \\
\text { country ready to compete with other country. }\end{array}$ \\
\hline 6. & $\begin{array}{l}\text { Today, I'm going to deliver a speech about something, } \\
\text { not so far from us but close to us, and we do this } \\
\text { everyday. I mean face it everyday. }\end{array}$ & $\begin{array}{l}\text { Lets do this and keep our environment clean and } \\
\text { healthy because it's for our life, to our health and } \\
\text { making life to more comfortable, no illness, no } \\
\text { disease. }\end{array}$ \\
\hline 7. & $\begin{array}{l}\text { In this occasion, please allow me to speak in front of } \\
\text { you about Bali is still safe for tourism. }\end{array}$ & $\begin{array}{l}\text {... according to my opinion, I think is always be a } \\
\text { special place, and if someday I'm a tourist and guide, } \\
\text { I will promote Indonesia especially Bali. }\end{array}$ \\
\hline 8. & $\begin{array}{l}\text { So now young generation is so important for building } \\
\text { this country. }\end{array}$ & $\begin{array}{l}\text { So, it's important for us to realize that we are the only } \\
\text { effort for this country. }\end{array}$ \\
\hline
\end{tabular}

As the purpose of persuasive text is to persuade and to convince, to finish it, an appeal/recommendation should be applied. The appeal/recommendation is stated to give a solution or a way out to certain problem proposed in the "marker". This move consists of an appeal to personally respond to an issue. It can be seen that two speakers use modal of necessity such as "must" (... we must prepare ourselves in the future for our country to be the best in the world) and "have to" (... every time you have to face with the changes ...). they have learned 
that the functions of these modals are to give a suggestion as it is implemented in the appeal/recommendation. Three speakers use the word "let”, such as "let me suggest”, "let we make”, and "let us work hard". These three speakers appeal the audience to do as they asked. One speaker used command to instruct, "just be happy". While one speaker used comparison to give suggestion, "Preventing now is better than dealing with it later".

"Closing" move consists of word or expression to finish a persuasive speech presentation. According to Price \& keefer (1995, p. 73), when making a public presentation always thank the chairperson for inviting and thank the audience for being attentive. Seven speakers mentioned "thank you". The speakers felt that there is a necessity to show their gratitude by saying thank you. They appreciated the audience's attention. Six speakers also greeted the audience. However, three of the speakers finished their presentation inappropriately by using "I think ... enough”. It can be assumed that this statement is influenced by Bahasa Indonesia which means "Cukup sampai disini" or "Cukup sekian”. This kind of closing is common in presenting a speech in Bahasa Indonesia. It can be considered that the speakers have not acquired English as it is used by the native speaker to close an oral presentation. In English way, to close a presentation, “That's all” is commonly used instead of "I think is enough". If the "opening marker" of the introductory stage and "closing" of the concluding stage are compared, the speakers seemed to be consistent to open and to finish their speech presentation (see Table 2).

Table 2

The Similarities Between "Opening Marker" and "Closing"

\begin{tabular}{|c|c|c|}
\hline Speeches & $\begin{array}{l}\text { ‘Opening marker’ } \\
\text { (Introductory Stage) }\end{array}$ & $\begin{array}{l}\text { 'Closing' } \\
\text { (Concluding Stage) }\end{array}$ \\
\hline Speech 1 & $\begin{array}{l}\text { Well, good morning, ladies and gentleman. It's an } \\
\text { honor for me to stand here in front of you to deliver } \\
\text { my speech. }\end{array}$ & $\begin{array}{l}\text { I think that's all for my speech, thank you, good } \\
\text { morning. }\end{array}$ \\
\hline Speech 2 & OK. Hi, hello, good morning. & You agrre with me? Yes, thank you. \\
\hline Speech 3 & Good morning ladies and gentlemen. & I think enough for me and good morning. \\
\hline Speech 4 & $\begin{array}{l}\text { Thanks for the time is given to me. The first, I'd like } \\
\text { to say thank to our God for the God's blessing so we } \\
\text { can come in the speech contest here. }\end{array}$ & $\begin{array}{l}\text { Ladies and gentlemen, the honorable judges, my } \\
\text { dearest lovely audience that will be all, thank you } \\
\text { very much for your attention and good morning. }\end{array}$ \\
\hline Speech 5 & $\begin{array}{l}\text { Good morning ladies and gentlemen, honorable jury } \\
\text { and all of the participants }\end{array}$ & $\begin{array}{l}\text { I think my speech is enough. Thanks very much } \\
\text { for your attention and good morning. }\end{array}$ \\
\hline Speech 6 & $\begin{array}{l}\text { Ass. Wr. Wb. Ladies and gentlemen, good morning. } \\
\text { Ehm. It's an honor for me to stand here in front of } \\
\text { you to give, deliver my speech and join this English } \\
\text { speech competition. }\end{array}$ & $\begin{array}{l}\text { I think that's it for me, hopefully we can make, } \\
\text { we can fix something up from my speech. I'd like } \\
\text { to say thank you to you all. Wass. Wr Wb. }\end{array}$ \\
\hline Speech 7 & $\begin{array}{l}\text { Ass. Wr. Wb. Good morning. Ladies and gentlemen, } \\
\text { the honorable jury and the audience. First of all, let } \\
\text { thank the Lord of the Almighty so that we can get } \\
\text { together here. }\end{array}$ & $\begin{array}{l}\text { And ladies and gentlemen, that all my speech and } \\
\text { if I make some mistakes please forgive me, and } \\
\text { thank you so much for your attention. Good } \\
\text { morning. }\end{array}$ \\
\hline Speech 8 & Ok, ehm, the honorly day. Ladies and gentlemen, & Ok. I think, it's enough thanks for the attention \\
\hline
\end{tabular}




\begin{tabular}{|l|l|l|}
\hline & $\begin{array}{l}\text { good morning, and Ass. Wr. Wb, ... and the } \\
\text { ooportunity to talking about ... }\end{array}$ & $\begin{array}{l}\text { and I hope you'll excuse of my lack of } \\
\text { preparation. Good morning, and wass. Wr. Wb. }\end{array}$ \\
\hline
\end{tabular}

Two speakers were consistent to start and to end their speeches with Moslem greetings, the leave-taking in Arabic expressions. Most of the participants also greeted (salute) again in the end of their speeches. Only one of the participants did not show her gratitude. Two speakers showed their gratitude to God because of His Bleesing they could follow the speech contest and were able to finish their presentation.

\section{The Sequence of Moves}

The Table 3 shows that the sequence of moves in the introductory stage, body stage, and concluding stage, generally follow the framework of speech genre. However, there is a variation of sequencing the moves in two speeches. In general, the alteration of the sequence of the moves does not change the argumentation. It is not influential. As long as all required moves are applied, variations of sequencing the moves do not influence the unity of the ideas presented.

In "claim", they present their opinion and show what point of view they belong to. In the "confutation" move, they fairly discuss the opposite view of their ideas. Then. In the "confirmation" move, they confirm their own ideas. In the "concession" move, they again show their point of view.

In the introductory stage, all of the moves are available ("opening marker", "gambit”, "narration”. And "marker”). In some cases, the sequences of the moves are varied. Instead of mentioning the "marker" at the end of the introductory stage, this move is placed after "gambit". In this case, the introductory stage is ended with a "narration". The sequence of the moves in the body stage are "claim". "confutation", "confirmation", and "concession". However, in two speeches, the sequence is started with "confutation", then followed by "confirmation" and "concession". The "claim" is located at the end of the sequence. In the concluding stage, "marker" starts the sequence and is finished by the "closing" as suggested in the sequence of moves in this stage. The move of "appeal/recommendation" is located between the "marker" and the "closing”. In some cases, the appeal and the recommendation are separated.

In sequencing the moves, there is a variety due to the speakers' cultural background. There were two speakers who could deliver a linear organization in the introductory stage. According to the table, speaker three and eight could make a "linear" introductory presentation although they are Javanese. Four other speakers (Javanese) ended their introductory stage with a narration. Despite, issuing the thesis (the issue/ "marker") at the end of the introductory stage, they closed this stage with a "narration". This is an evidence of spiral/circular structure in the introductory stage as shown by speaker one (Chinese) and speaker five (Javanese). They repeated the "gambit."

Table 3

The Sequence of Moves in the Persuasive Speech Genre Made by the Speech Contestants (high school students)

\begin{tabular}{|l|l|l|l|}
\hline & Introductory stage & Body stage & Concluding stage \\
\hline Speech 1 & Opening & Claim & Marker \\
& Gambit & Confutation & Appeal \\
& Marker & Confirmation & closing \\
\hline
\end{tabular}




\begin{tabular}{|c|c|c|c|}
\hline & $\begin{array}{l}\text { Narration } \\
\text { Gambit } \\
\text { Marker }\end{array}$ & Concession & \\
\hline Speech 2 & $\begin{array}{l}\text { Opening } \\
\text { Gambit } \\
\text { Marker } \\
\text { Narration }\end{array}$ & $\begin{array}{l}\text { Gambit } \\
\text { Narration } \\
\text { Gambit } \\
\text { Narration } \\
\text { Claim } \\
\text { Confutation } \\
\text { Confirmation } \\
\text { Concession } \\
\text { Gambit } \\
\text { Narration } \\
\text { Gambit } \\
\text { Confutation } \\
\text { Confirmation } \\
\text { Concession } \\
\text { Confutation } \\
\text { Confirmation } \\
\text { Concession } \\
\text { Claim }\end{array}$ & $\begin{array}{l}\text { Gambit } \\
\text { Marker } \\
\text { Appeal } \\
\text { Closing }\end{array}$ \\
\hline Speech 3 & $\begin{array}{l}\text { Opening } \\
\text { Gambit } \\
\text { Narration } \\
\text { Marker }\end{array}$ & $\begin{array}{l}\text { Claim } \\
\text { Confutation } \\
\text { Confirmation } \\
\text { Concession } \\
\text { Claim } \\
\text { Confutation }\end{array}$ & $\begin{array}{l}\text { Marker } \\
\text { Appeal } \\
\text { Gambit } \\
\text { Confutation } \\
\text { Closing }\end{array}$ \\
\hline Speech 4 & $\begin{array}{l}\text { Opening } \\
\text { Gambit } \\
\text { Marker } \\
\text { Narration }\end{array}$ & $\begin{array}{l}\text { Confutation } \\
\text { Confirmation } \\
\text { Concession } \\
\text { Gambit } \\
\text { Claim } \\
\text { Confutation } \\
\text { Confirmation } \\
\text { Concession } \\
\text { Gambit } \\
\text { Claim } \\
\text { Claim }\end{array}$ & $\begin{array}{l}\text { Marker } \\
\text { Appeal } \\
\text { Closing }\end{array}$ \\
\hline
\end{tabular}




\begin{tabular}{|c|c|c|c|}
\hline & & $\begin{array}{l}\text { Confutation } \\
\text { Confirmation } \\
\text { Concession } \\
\text { Claim } \\
\text { Confutation } \\
\text { Confirmation } \\
\text { Concession } \\
\text { Claim } \\
\text { Confutation } \\
\text { Confirmation } \\
\text { Concession } \\
\text { Claim } \\
\text { Confutation } \\
\text { Confirmation } \\
\text { Concession } \\
\text { Claim } \\
\text { Confutation } \\
\text { Confirmation Concession } \\
\text { Claim } \\
\text { Confutation } \\
\text { Confirmation } \\
\text { Concession } \\
\text { Claim } \\
\text { Confutation } \\
\text { Confirmation } \\
\text { Concession }\end{array}$ & \\
\hline Speech 5 & $\begin{array}{l}\text { Opening } \\
\text { Gambit } \\
\text { Marker } \\
\text { Gambit } \\
\text { Narration }\end{array}$ & $\begin{array}{l}\text { Claim } \\
\text { Confutation } \\
\text { Confirmation } \\
\text { Concession } \\
\text { Confirmation } \\
\text { Claim } \\
\text { Confutation } \\
\text { Confirmation } \\
\text { Concession } \\
\text { Claim } \\
\text { Confutation } \\
\text { Confirmation }\end{array}$ & $\begin{array}{l}\text { Marker } \\
\text { Appeal } \\
\text { Closing }\end{array}$ \\
\hline
\end{tabular}




\begin{tabular}{|c|c|c|c|}
\hline & & Concession & \\
\hline Speech 6 & $\begin{array}{l}\text { Opening } \\
\text { Gambit } \\
\text { Marker } \\
\text { Narration }\end{array}$ & $\begin{array}{l}\text { Claim } \\
\text { Confutation } \\
\text { Confirmation } \\
\text { Concession } \\
\text { Claim } \\
\text { Confutation } \\
\text { Confirmation } \\
\text { Concession } \\
\text { Claim } \\
\text { Confutation } \\
\text { Confirmation } \\
\text { Concession }\end{array}$ & $\begin{array}{l}\text { Marker } \\
\text { Appeal } \\
\text { Recommendation } \\
\text { closing }\end{array}$ \\
\hline Speech 7 & $\begin{array}{l}\text { Opening } \\
\text { Gambit } \\
\text { Marker } \\
\text { Narration }\end{array}$ & $\begin{array}{l}\text { Claim } \\
\text { Confutation } \\
\text { Confirmation } \\
\text { Concession } \\
\text { Claim } \\
\text { Confutation } \\
\text { Confirmation } \\
\text { Concession }\end{array}$ & $\begin{array}{l}\text { Marker } \\
\text { Recommendation } \\
\text { Narration } \\
\text { Closing }\end{array}$ \\
\hline Speech 8 & $\begin{array}{l}\text { Opening } \\
\text { Gambit } \\
\text { Narration } \\
\text { Marker }\end{array}$ & $\begin{array}{l}\text { Claim } \\
\text { Confutation } \\
\text { Confirmation } \\
\text { Concession } \\
\text { Claim } \\
\text { Confutation } \\
\text { Confirmation concession } \\
\text { Claim } \\
\text { Confutation } \\
\text { Confirmation } \\
\text { Concession } \\
\text { Claim } \\
\text { Confutation } \\
\text { Confirmation } \\
\text { Concession }\end{array}$ & $\begin{array}{l}\text { Gambit } \\
\text { Marker } \\
\text { Recommendation } \\
\text { Appeal closing }\end{array}$ \\
\hline
\end{tabular}

In the body stage, four speakers, speaker number one (Chinese) and speakers number six, seven, and eight (Javanese), constructed their ideas linearly based on the framework proposed. However, four other speakers, 
speaker two (Chinese) and speakers number three, four, and five (Javanese), did not follow either linear or circular model of organising/sequencing the micro-moves in one section of the body stage. One Chinese speech contest participant repeated "gambit" and "narration". In the beginning of the body stage, the speaker did not state the "claim" and the other micro-moves, instead she constructed her ideas circularly by repeating the “attention grabber" (gambit) and "story” (narration). However, she sequenced her ideas as proposed. It seemed that speaker three (Javanese) did not finish discussing her ideas in the body stage. She repeated the sequence but she did not construct the second sequence completely. In speech four, the speaker (a Javanese) inserted "gambit" after sequencing the micro-moves. It happened in the beginning of presenting the body stage. The rest of the body stage presentation, she constructed her ideas based on the proposed framework. As it is presented in speech 5 , the speaker repeated the 'confirmation' after the first sequence.

In the concluding stage, most of the speakers could construct the micro-moves as proposed in the framework. One chinese speaker (speech 1) followed the proposed model. However, the other Chinese speaker postponed to state the issue in the beginning of the concluding stage. Moreover, three javanese speakers constructed the concluding stage by following the framework proposed. One Javanese speaker initiated the concluding stage by mentioning the issue (“marker”). However, before "closing”, she inserted "gambit” and "confutation”. Four Javanese speakers stated an apology in the concluding stage as it is influenced by javanese culture to apologize to finish an activity.

\section{Conclusion}

Senior high school students have already known how to construct sentences, however, they have sketchy knowledge of schematic text structure. The students have already known that a speech consists of introduction, body, and conclusion. However, they do not know how to construct the schematic structure of a text appropriately. Therefore, it is necessary to teach high school students how to construct a text. By teaching high school students the schematic structure of a text, the students will not only master good grammatical form, but also the appropriateness of language use in real social context.

In short, there is a necessity to learn the components of atext. As it is required as a competence of learning English in Indonesia, presenting a speech must be tailored for instructional process in the classroom. Teaching English is not the same with teaching rules of a language only. To teach English, an English teacher may not just assign his/her students to produce a certain text without explaining the components of a text. In addition, the English teacher should also explain the cultural load of a text so that the students do not sound bookish. At the same time, when learning a language, the English learners should equip themseleves with the knowledge to construct a text. By paying attention to the schematic structure of a text, the English learners can create appropriate texts the English way. It would be better if the English teacher has the knowledge of the rhetorical organisation (macro stages and micro moves) of a certain text. This would help the students to be able to use English like a native speaker of English.

\section{References}

Agustien, H. I. R. (2004). The 2004 English curriculum in a Nutshell (A paper presented at the 50th Anniversary of the English Department Universitas Negeri Malang. Malang: Universitas Negeri Malang) 
Badan Stándar Nasional Pendidikan (BSNP/The Agency of Educational National Standard). (2006). Kurikulum Tingkat Satuan Pendidikan/KTSP (Curriculum of National Educational Level). BSNP, 307-320.

Balcer, C. L., \& Seabury, H. F. (1965). Teaching speech in today's secondary school. New York: Holt, Rinehart and Winston, Inc. Bhatia, V. K. (1993). Analysing genre: Language use in professional settings. London: Longman.

Bhatia, V. K. (1997a). Applied genre analysis:A multi-perspective model (pp. 134-135). Hong Kong: City University of Hong Kong.

Bhatia, V. K. (1997b). Applied genre analysis and ESP. In T. Miller (Ed.), Functional approaches to written text: Classroom application. Washington, DC: English Language Programs.

Birk, N. P., \& Birk, G. B. (1986). Selection, slanting, and charged language. Exploring Language. Toronto: Little, Brown Company.

Black, P. (1995). The dance of language: Some practical linguistic approaches. Centre for Studies of Language in Education. Darwin: Northern Territory University.

Blount, B. G. (ed.), (1974). Language, culture and society: A book of readings (pp. 86-111). Cambridge, Mass: Winthrop.

Cayne, B. S. et al., (Eds.). (1988). Encyclopedic dictionary of the English language. New York: Lexicon Publication, Inc.

Celce-Murcia, M., \& Olshtain, E. (2000). Discourse and context in language teaching: A guide for language teachers (p. 170). England: Cambridge University Press.

Cheong, E.-Y. (1999). Analysis of Sermons delivered by Korean, Filipino, and American Pastors: The view of genre analysis. FORUM, 30(4), 44-45.

Cooper, S., \& Patton, R. (2003). Writing logically, thinking critically. New York: Pearson Longman.

D’Angelo, F. J. (1980). Process and thought in composition. Cambridge: Winthrop Publishers, Inc.

De Beaugrande, R. A., \& Dressler, W. (1981). Text linguistics: An introduction. King Saud University: College of Language and Translation Department of English and Translation.

Department of National Education. (2004). Kurikulum 2004: Standar Kompetensi (Curriculum 2004: Standar of competencies) ( p. 42). Depdiknas.

Derewianka, B. (1995). Exploring how texts work. Sydney: Primary English Teaching Association (Australia).

Fawcett, S., \& Sandberg, A. (1988). Evergreen: A guide to writing. Boston: Houghton Mifflin Company.

Golden, J. L. et al. (1984). The rhetoric of western thought. Iowa: Kendall/Hunt Publishing Company.

Hammond, J. (1987). An overview of the genre-based approach to the teaching of writing. Australian Review of Applied Linguistics, 10(2), 163-181.

Kaplan, R. B. (1966). Cultural thought patterns in inter-cultural education. Language Learning, 16, 1-20. (Reprinted in 1972 and 1980 (2nd ed.) in K. Croft (Ed.), Reading son English as a second language: For teachers and teacher trainers (pp. 399-418), Winthrop; and in 1984 in S. McKay (Ed.), Composing in a second language (pp. 43-56), Newbury House, Rowley MA.

Kern, R. (2000). Literacy and language teaching. Hongkong: Oxford University Press.

Lazaraton, A. (2001). Teaching oral skills (p. 106). Boston: Heinle \& Heinle.

Literacy \& Education Research Network. (1990). A genre-based approach to teaching writing in years 3-6. Annandale: Common Ground.

Mann, W. C., \& Thompson, S. A. (1992). Discourse description: Diverse linguistic analyses of a fund-raising text. Amsterdam/Philadelphia: John Benjamins Publishing Company.

Martin, J. R. (1984). Language, register and genre. In F. Christie (Ed.), Children writing reader. Geelong Vic: Deakin University.

Ngadiman, A. (1998). Javanese cultural thought patterns as manifested in expository discourse (Unpublished Dissertation. Malang: Institute of Teacher Training and Education).

Nutall, C. E. (1982). Teaching reading skills in a foreign language. Heneimann Educational Books.

Price, K. R., \& Keefer, J. (1995). Communication skills: Using the telephone, conducting a meeting, making a speech. Columbus: Vocational Instructional Materials Laboratory.

Savignon, S. J. (2001). Communicative language teaching for the Twenty-First century. Teaching english as a second \& foreign language ed. Marianne Celce-Murcia. Heinel \& Heinel.

Seyler, D. U. (1984). Beginning with strategies for reading accurately and identifying the writer's article, the text moves on to argument, logic and research. Northern Virginia: Community College.

Shumin, K. (1997). Factors to consider: Developing adult EFL students’ speaking abilities. FORUM, 35(3), 9-10.

Sinar, T. S. (2002). An introduction to a systemic-functional linguistic-oriented discourse analysis. Singapore: Deezed Consult. 
Susilo, S. (1998). Rhetorical patterns as reflected in argumentation discourse in the Jakarta post articles (Unpublished Thesis. Malang: Institute of Teacher Training and Education).

Swales, J. M. (1991). ESP development worldwide. In Luzares et al. (Eds.), Proceedings of the ESP State-of-the-Art Conference (pp. 11-19). Manila: De La Salle University..

Titscher, S. et al. (2000). Methods of texts and discourse analysis. London: SAGE Publications Ltd.

Tong, W. (1999). A public speaking course. In FORUM, 37(1), 26. Jan-Mar. Washington, DC: English Teaching Forum.

Wahab, A. (1991). Isu linguistik: Pengajaran Bahasa dan Sastra (Teaching learning language \& literature: Linguistic issue). Surabaya: Airlangga University Press.

Webster, M. (1990). The new lexicon dictionary of the English language. New York: Lexicon Publication. Inc.

Wignell, P. (1994). Introduction to English grammar and discourse: Study guide. Darwin: NT External Studies Centre, Northern Territory University.

Yang. S. Y. (1999). Classroom speaking activities. FORUM, 37(4), 22. 